\title{
PENGGUNAAN STRATEGI PEER TUTORING UNTUK MENINGKATKAN PENGUASAAN DIRI SISWA DALAM PELAJARAN MATEMATIKA KELAS XII.MIPA.1 SMAN 2 KOTA JAMBI TAHUN PELAJARAN 2018-2019
}

\author{
SITI ZUBAIDAH \\ SMA Negeri 2 Kota Jambi, Provinsi Jambi \\ Email : sitizubaidah6666@gmail.com
}

\begin{abstract}
ABSTRAK
Penelitian ini bertujuan untuk meningkatkan rasa penguasaan diri siswa dalam mata pelajaran Matematika pada siswa kelas XII SMA Negeri 2 Kota Jambi melalui strategi peer tutoring. Penelitian ini adalah Penelitian Tindakan Kelas (PTK). Dalam penelitian ini yang menjadi subjek penelitian yaitu guru dan siswa SMA Negeri 2 Kota Jambi, khususnya kelas XII.MIPA.1. Kelas XII.MIPA.1 berjumlah 35 siswa, terdiri dari 10 siswa laki-laki dan 25 siswa perempuan. Teknik pengumpulan data yang digunakan dalam penelitian ini adalah wawancara, observasi, dan studi dokumentasi. Hasil penelitian menunjukkan adanya peningkatan rasa penguasaan diri dalam mata pelajaran Matematika pada siswa kelas XII SMA Negeri 2 Kota Jambi dengan menggunakan strategi peer tutoring. Hal ini dapat dilihat dengan peningkatan: keberanian siswa mengajukan pertanyaan dari 2 siswa $(5,71 \%)$ menjadi 23 siswa $(65,71 \%)$. Siswa yang aktif menanggapi pertanyaan yang diberikan Guru dari 3 siswa $(8,57 \%)$ menjadi 26 siswa $(74,29 \%)$. Siswa yang berani mengerjakan soal di depan dari 11 siswa $(31,43 \%)$ menjadi 29 siswa $(82,86 \%)$. Berdasarkan hasil penelitian dapat disimpulkan bahwa pembelajaran menggunakan strategi peer tutoring sangat efektif dalam meningkatkan rasa penguasaan diri siswa dalam belajar matematika
\end{abstract}

Kata Kunci:peer tutoring, penguasaan diri, matematika

\section{PENDAHULUAN}

Pendidikan merupakan upaya dan usaha yang dilakukan oleh keluarga, masyarakat, dan pemerintah, melalui kegiatan bimbingan, pengajaran, dan latihan, yang berlangsung di sekolah dan di luar sekolah untuk mempersiapkan peserta didik agar dapat memainkan peranan dalam berbagai lingkungan hidup secara tetap untuk masa yang akan datang. Tetapi pada prosesnya, kegiatan belajar dan mengajar dalam dunia pendidikan banyak persoalan yang muncul. Baik itu masalah kekurangan guru mengajar, kurangnya sarana dan prasarana pendidikan, sistem yang sering berubah- ubah, birokrasi Pemerintah, maupun masalah-masalah yang terjadi dalam diri siswa.

Di lingkungan sekolah itu sendiri setiap siswa diharapkan dapat memaksimalkan seluruh potensi yang dimilikinya. Akan tetapi pada kenyataannya masih banyak siswa yang belum dapat memaksimalkan seluruh potensi yang dimilikinya. Salah satu masalah yang sering dihadapi oleh siswa adalah rendahnya penguasaan diri. Ini terlihat dari masih terdapat beberapa siswa yang belum dapat memahami suatu pelajaran secara tuntas. Hal ini disebabkan Guru yang tidak dapat menciptakan suasana belajar yang kondusif, atau belum menemukan metode pembelajaran yang tepat.

Di dalam proses pembelajaran, sangat dibutuhkan strategi yang tepat supaya pembelajaran menjadi menyenangkan dan pelajaran matematika tidak menjadi momok yang ditakuti para siswa. Juga supaya para siswa menjadi lebih penguasaan diri. Pendidikan matematika di sekolah saat ini sedang mengalami perubahan paradigma. Pemerintah memberikan perhatian lebih terhadap pembelajaran matematika sekolah, hal ini dapat dilihat dari penambahan jam pelajaran matematika dalam Kurikulum 2013 sesuai dengan Permendikbud No 69 tahun 2013 tentang kerangka dasar dan struktur kurikulum Sekolah Menengah Atas /Madrasah Aliyah. (Rosanti, 2018: 1-10). Sejalan dengan karakteristik matematika yang dikemukakan oleh Soemarmo (2014:6) bahwa visi pertama pembelajaran matematika adalah mengarahkan pembelajaran matematika untuk pemahaman konsep dan ide 
matematika yang dapat digunakan untuk menyelesaikan masalah matematika dan ilmu pengetahuan lainnya.

Salah satu strategi yang coba penulis tawarkan dalam hal ini adalah bagaimana menumbuhkan rasa penguasaan diri dengan menjadi tutor bagi siswa yang lain. Agar siswa dapat aktif dalam proses pembelajaran guru sebagai fasilitator hendaknya menyediakan pengalaman belajar yang dapat membantu siswa mengembangkan seluruh potensi dirinya, siswa dapat membangun pengetahuannya melalui kerjasama dengan teman sebayanya melalui bimbingan guru (Mujiarso, 2014:1- 10).

Tutor yang sebaya bisa melatih siswa untuk belajar mengkomunikasikan materi atau cara mengerjakan soal matematika dengan temannya sehingga secara tidak langsung rasa penguasaan diri dapat ditumbuhkan dari kegiatan tersebut. Meskipun untuk menjadi tutor yang baik, siswa harus paham dahulu mengenai salah satu materi atau konsep matematika. Berangkat dari pandangan bahwa setiap siswa memiliki kemampuan penguasaan yang berbeda, maka diperlukan adanya suatu metode yang mampu meningkatkan kemampuan penguasaan matematika siswa secara merata. Kemampuan untuk menyerap materi dalam sebuah topik pembelajaran matematika pada umumnya berbeda antara satu peserta didik dan peserta didik lainnya. Siswa cenderung memandang pelajaran Matematika sebagai pelajaran yang sulit karena membutuhkan kemampuan yang tinggi dalam memahami konsep-konsep abstrak. Ketidakmampuan menguasai konsep-konsep abstrak menyebabkan hasil belajar matematika siswa cenderung tidak maksimal. (Tana, Supriyoko, Haryanto, 2017: 37-43).

Menurut Djamarah, kelebihan menggunakan metode tutor sebaya diantaranya adalah dapat menambah motivasi belajar, efisien, meningkatkan rasa tanggung jawab akan kepenguasaan, juga terciptanya suasana hubungan yang lebih akrab dan dekat antara siswa yang dibantu dengan siswa sebagai tutor yang membantu (Djamarah dan Zain, 2006).

Hasil belajar yang diharapkan ialah agar anggota kelompok belajar menghargai pendapat orang lain, menumbuhkan rasa penguasaan diri pada diri sendiri dalam mengembangkan ide-ide yang ditemukannya yang dianggap benar (Hasibuan dan Moedjiono, 2010). Penguasaan diri adalah penilaian positif terhadap diri sendiri mengenai kemampuan yang ada dalam dirinya untuk menghadapi berbagai situasi dan tantangan serta kemampuan mental untuk mengurangi pengaruh negatif dari keragu-raguan yang mendorong individu untuk meraih keberhasilan atau kesuksesan tanpa tergantung kepada pihak lain dan bertanggung jawab atas keputusan yang telah ditetapkannya.

Kondisi awal siswa kelas XII.MIPA.1 SMA Negeri 2 Kota Jambi Tahun Pelajaran 2018-2019 cenderung kurang penguasaan diri. Hal ini terlihat dari hanya beberapa siswa yang penguasaan diri bertanya, hanya beberapa siswa yang penguasaan diri menanggapi pertanyaan dari Guru, serta hanya beberapa siswa yang nampak penguasaan diri dalam mengerjakan soal di depan. Hal ini disebabkan guru yang kurang optimal dalam memilih strategi pembelajaran. Strategi yang tepat yang ditawarkan dalam penelitian ini yaitu strategi tutor teman sebaya. Strategi ini mengharuskan siswa yang relatif pandai mengajari temannya yang lain. Kegiatan ini dapat efektif karena sesama siswa biasanya tidak canggung dalam penyampaian materi.

Observasi dilakukan pada siswa kelas XII.MIPA.1 SMA Negeri 2 Kota Jambi Tahun Pelajaran 2018-2019 yang jumlahnya 35 siswa, yang terdiri dari 10 siswa laki-laki dan 25 siswa perempuan. Diperoleh data penguasaan diri siswa yang mengajukan pertanyaan sebanyak 2 siswa $(5,71 \%)$, siswa yang penguasaan diri menanggapi pertanyaan yang di berikan guru 3 siswa $(8,57 \%)$ dan siswa yang penguasaan diri mengerjakan soal latihan di depan kelas adalah 11 siswa $(31,43 \%)$. Berdasarkan hasil observasi tersebut dapat dikatakan bahwa rasa penguasaan diri siswa XII.MIPA.1 SMA Negeri 2 Kota Jambi Tahun Pelajaran 2018-2019 masih rendah.

Menyikapi adanya permasalahan yang ada berdasarkan informasi sebelumnya pada bagian observasi, menunjukkan pentingnya dilakukkan pengembangan pendekatan pembelajaran matematika guna meningkatkan rasa penguasaan diri siswa. Oleh karena itu, peneliti melakukan pembelajaran dengan menggunakan strategi Peer Tutoring. Pembelajaran 
Peer Tutoring merupakan cara yang efektif untuk menghasilkan kemampuan mengajar teman sebaya (Silberman 2001). Pemilihan metode pembelajaran tutor sebaya merupakan salah satu alternatif yang dapat diterapkan kepada siswa dalam proses pembelajaran yang dilakukan dengan kelompok kecil. Tujuan dari proses pembelajaran dengan kelompok adalah: 1) meningkatkan partisipasi optimal siswa dalam belajar, 2) memberi pelajaran kepemimpinan dan pengalaman membuat keputusan kelompok, 3) memberi kesempatan untuk berinteraksi dan belajar dengan siswa lain yang berasal dari latar belakang budaya (kebiasaan) dan kemampuan yang berbeda (Kosasih, 2014:101). Dengan metode pembelajaran secara berkelompok yang dipimpin oleh seorang tutor diharapkan siswa memiliki kemampuan yang lebih baik secara kognitif (pengetahuan) dan keterampilan. Hal ini sejalan dengan pendapat Hanik \& Harsono (2016:25-31) bahwa dengan pendekatan kooperatif (kelompok) dapat mendorong dan memberi kesempatan siswa untuk terampil berkomunikasi dan membentuk konsep baru bersama temannya maka akan terjadi peningkatan aktivitas dan hasil belajar.

\section{METODE PENELITIAN}

Penelitian ini merupakan Penelitian Tindakan Kelas (PTK) yang dilaksanakan secara kolaboratif antara guru matematika yang lain dan peneliti untuk memperbaiki kegiatan proses pembelajaran di kelas. Penelitian ini diawali dengan dialog awal yang dilakukan oleh peneliti. Berdasarkan pada dialog awal dan kegiatan observasi, peneliti dan guru sepakat akan meningkatkan rasa penguasaan diri siswa, serta guru menerima solusi yang diajukan oleh peneliti untuk menerapkan pendekatan Peer Tutoring dalam kegiatan belajar mengajar.

Dialog awal dilakukan oleh peneliti pada tanggal 18 September 2018. Kemudian, peneliti melakukan observasi pada tanggal 19 September 2018 untuk mengetahui permasalahan dan beberapa kendala yang terjadi pada siswa dan guru saat proses belajar mengajar berlangsung. Kemudian berlangsung Siklus I selama dua kali pertemuan. Materi pembelajaran pada pertemuan pertama yaitu Sistem Persamaan Linier Tiga Variabel dengan indikator menentukan himpunan penyelesaian dari Sistem Persamaan Linier Tiga Variabel dengan menggunakan metode substitusi dan eliminasi. Sedangkan pada pertemuan kedua indikatornya adalah menentukan himpunan penyelesaian dari Sistem Persamaan Linier Tiga Variabel dengan menggunakan metode Cramer. Teknik pengumpulan data yang digunakan dalam penelitian ini adalah wawancara, observasi, dan studi dokumentasi. Indikator capaian diantaranya kepenguasaan diri siswa mengajukan pertanyaan $65 \%$, siswa yang penguasaan diri menanggapi pertanyaan yang di berikan guru $70 \%$, dan siswa yang penguasaan diri mengerjakan soal di depan kelas $80 \%$.

\section{HASIL DAN PEMBAHASAN}

Penelitian ini dilaksanakan melalui tahap-tahap yaitu perencanaan, pelaksanaan dan refleksi tindakan. Perencanaan tindakan dilaksanakan pada hari Selasa, tanggal 18 September 2018. Hasilnya kemudian peneliti tuangkan kedalam RPP yang peneliti susun. Dimana perencanaan tindakan kelas pada Siklus I akan dilaksanakan dalam 2 kali pertemuan. Dan setiap pertemuan dilaksanakan selama 2 jam pelajaran. Peneliti akan membantu guru dalam proses pembelajaran dan akan bertindak sebagai observer. Sedangkan siswa kelas XII.MIPA.1 akan bertindak sebagai penerima tindakan.

\section{Siklus I}

Pertemuan pertama dilaksanakan pada hari Senin, tanggal 24 September 2020 pada pukul 12.30 - 13.50 WIB. Pelaksanaan tindakan kali ini dimaksudkan untuk meningkatkan rasa penguasaan diri siswa, yang dapat dilihat dari rasa penguasaan diri siswa di dalam kelompok, rasa penguasaan diri siswa dalam bertanya, dan rasa penguasaan diri siswa dalam mengerjakan tugas di depan kelas. Peneliti bersama guru melaksanakan pembelajaran sesuai dengan RPP yang peneliti susun. Pertemuan kedua berlangsung pada hari Selasa, tanggal 25 September 2018 pukul 07.00 - 08.30 WIB. Setelah Guru menyebutkan manfaat materi yang akan dipelajari bagi kehidupan sehari-hari, seperti halnya pada pertemuan pertama, Guru menjelaskan model 
pembelajaran Peer Tutoring supaya peserta didik lebih paham dan dapat mengikuti kegiatan pembelajaran dengan baik.

Refleksi tindakan kelas dilaksanakan pada hari Selasa, tanggal 25 September 2018 diskusikan hasil penelitian dan catatan-catatan yang nantinya akan digunakan sebagai bahan pertimbangan juga tindak lanjut pada Siklus II. Hasil dari diskusi peneliti dan guru adalah tindakan mengajar guru dalam menerapkan strategi Peer Tutoring belum mengalami perubahan yang di harapkan, karena guru belum mampu mengaplikasikan strategi Peer Tutoring dan siswa masih kebingungan dengan apa yang harus dilakukan. Pada intinya siswa belum terbiasa melakukan pembelajaran dengan berbasis kelompok. Untuk mengatasi hal tersebut, peneliti berupaya memberikan arahan yang jelas untuk melakukan pembelajaran strategi Peer Tutoring. Siklus II

Pelaksanaan tindakan Siklus II dilaksanakan dalam 2 kali pertemuan. Pertemuan pertama dilaksanakan pada hari Senin, tanggal 15 Oktober 2018 pada pukul 09.30-11.00 WIB. Materi pembelajaran pada Siklus II pertemuan pertama yaitu Sistem Persamaan Linier Tiga Variabel dengan indikator membuat model matematika Sistem Persamaan Linier Tiga Variabel dari masalah kontekstual. Sedangkan pada pertemuan kedua indikatornya adalah menyelesaikan masalah kontekstual yang berkaitan dengan Sistem Persamaan Linier Dua Variabel.

Refleksi tindakan kelas pada siklus II dilaksanakan pada hari Selasa, tanggal 16 Oktober 2018 setelah kegiatan belajar mengajar berakhir. Peneliti bersama Guru kembali mendiskusikan hasil dari penelitian tersebut. Berdasarkan hasil penelitian, catatan-catatan, ternyata setelah sampai Siklus II siswa baru mengerti tentang pembelajaran Peer Tutoring. Siswa mulai terbiasa dengan diskusi kelompok, bertanya, dan mengerjakan soal di depan. Kelas lebih bisa dikondisikan sehingga diskusi menjadi lebih efektif. Siswa menjadi lebih fokus memperhatikan yang disampaikan oleh Guru.

Berdasarkan penelitian yang telah dilakukan, peningkatan rasa penguasaan diri siswa sebelum tindakan sampai dengan tindakan Siklus II dapat dilihat dari data berikut: (1) Pada siklus I pertemuan pertama, siswa yang penguasaan diri bertanya sebanyak 17 siswa $(48,51 \%)$. Siswa yang penguasaan diri menanggapi pertanyaan yang diberikan Guru sebanyak 18 siswa $(51,43 \%)$. Dan siswa yang penguasaan diri mengerjakan soal di depan sebanyak 20 siswa $(57,14 \%)$. (2) Sedangkan siklus I pada pertemuan kedua, diperoleh data sebagai berikut. Siswa yang penguasaan diri bertanya sebanyak 19 siswa (54,29\%). Siswa yang penguasaan diri menanggapi pertanyaan yang diberikan Guru sebanyak 15 siswa $(42,86 \%)$. Dan siswa yang penguasaan diri mengerjakan soal di depan sebanyak 21 siswa (60\%). (3) Pada siklus II petemuan pertama, diperoleh data sebagai berikut. Siswa yang penguasaan diri bertanya sebanyak 24 siswa $(68,57 \%)$. Siswa yang penguasaan diri menanggapi pertanyaan yang diberikan Guru sebanyak 25 siswa (71,43\%). Dan siswa yang penguasaan diri mengerjakan soal di depan sebanyak 31 siswa $(88,57 \%)$. (4) Sedangkan Siklus II pada pertemuan kedua, diperoleh data sebagai berikut. Siswa yang penguasaan diri bertanya sebanyak 23 orang $(65,71 \%)$. Siswa yang penguasaan diri menanggapi pertanyaan yang diberikan Guru sebanyak 26 orang $(74,29 \%)$. Dan siswa yang penguasaan diri mengerjakan soal di depan sebanyak 29 orang $(82,86 \%)$.Lebih jelasnya dapat dilihat pada tabel berikut:

Tabel 1 Data Peningkatan Rasa Penguasaan Diri Siswa

\begin{tabular}{cccc}
\hline Indikator & $\begin{array}{c}\text { RasaPenguasaa } \\
\text { ndiri } \\
\text { dalambertanya }\end{array}$ & $\begin{array}{c}\text { Rasapenguasaa } \\
\text { ndiridalamm } \\
\text { enanggapi }\end{array}$ & $\begin{array}{c}\text { Rasa penguasaan } \\
\text { diridalammengerj } \\
\text { akansoal }\end{array}$ \\
Sebelum & 2 siswa & 3 siswa & 11 siswa \\
Tindakan & $(5,71 \%)$ & $(8,57 \%)$ & $(31,43 \%)$ \\
Siklus I & 17 siswa & 18 siswa & 20 siswa \\
Pertemuan 1 & $(48,51 \%)$ & $(51,43 \%)$ & $(57,14 \%)$ \\
\hline
\end{tabular}




\begin{tabular}{cccc}
\hline Siklus I & 19 siswa & 15 siswa & 21 siswa \\
Pertemuan 2 & $(54,29 \%)$ & $(42,86 \%)$ & $(60 \%)$ \\
Siklus II & 24 siswa & 25 siswa & 31 siswa \\
Pertemuan 1 & $(68,57 \%)$ & $(71,43 \%)$ & $(88,57 \%)$ \\
Siklus II & 23 siswa & 26 siswa & 29 siswa \\
Pertemuan 2 & $(65,71 \%)$ & $(74,29 \%)$ & $(82,86 \%)$
\end{tabular}

Pembelajaran dengan strategi Peer Tutoring sangat efektif dalam meningkatkan rasa penguasaan diri siswa. Data hasil pengamatan tersebut, mulai dari kondisi sebelum tindakan sampai kondisi sesudah tindakan, Siklus I maupun Siklus II akan peneliti sajikan pula dalam bentuk grafik sebagai berikut:

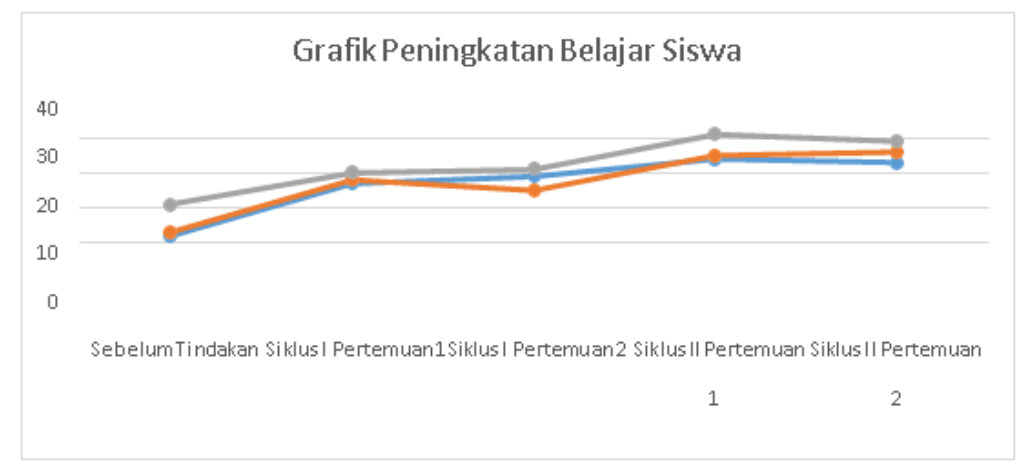

\section{Gambar 1. Grafik Peningkatan Rasa Penguasaan Diri Siswa}

Pembelajaran dengan strategi Peer Tutoring sangat efektif dalam meningkatkan rasa penguasaan diri siswa. Kegiatan pembelajaran pertemuan pertama maupun pertemuan kedua menjadi lebih menyenangkan dan siswa lebih antusias dalam proses pembelajaran. Sudah banyak siswa yang penguasaan diri bertanya, menyampaikan pendapat, maupun menanggapi pertanyaan dari Guru. Siswa juga menjadi lebih teliti terhadap masalah-masalah yang diberikan. Siswa mulai terbiasa dengan diskusi kelompok, bertanya, dan penguasaan diri mengerjakan soal di depan. Kelas lebih bisa dikondisikan sehingga diskusi menjadi lebih efektif. Siswa menjadi lebih fokus memperhatikan yang disampaikan oleh Guru.

Hasil penelitian ini didukung oleh Ruseno Arjanggi dan Titin Suprihatin (2010) menyimpulkan pembelajaran tutor teman sebaya terbukti memberikan kontribusi munculnya perilaku belajar berdasar regulasi-diri pada mahasiswa. Nur Afifah (2011) menyimpulkan bahwa penggunaan strategi pembelajaran tutor sebaya meningkatkan hasil belajar Matematika. Murwani Dian Ekaristi (2012) menyimpulkan bahwa layanan bimbingan kelompok efektif untuk meningkatkan kepenguasaanan diri siswa. Satyani, Ida Ayu Putu Satyani, I Nyoman Dantes, dan I Made Candiasa (2014) menyimpulkan adanya perbedaan prestasi belajar matematika antara siswa yang mengikuti model kooperatif teknik tutor sebaya.

Berdasarkan hasil penelitian dapat disimpulkan bahwa Pembelajaran dengan strategi Peer Tutoring sangat efektif dalam meningkatkan rasa penguasaan diri siswa dalam belajar matematika. Oleh karena itu, hipotesis dapat diterima sehingga ada peningkatan rasa penguasaan diri belajar matematika siswa melalui strategi Peer Tutoring di kelas XII.MIPA.1 SMA Negeri 2 Kota Jambi Tahun Pelajaran 2018-2019.

\section{KESIMPULAN}

Berdasarkan penelitian yang telah dilakukan di kelas dapat di simpulkan bahwa rasa penguasaan diri siswa mengalami peningkatan pada Siklus I maupun Siklus II. Peningkatan rasa penguasaan diri siswa dapat dilihat dari data sebagai berikut: (a) Data hasil tindakan kelas menunjukan bahwa siswa yang penguasaan diri mengajukan pertanyaan mengalami peningkatan. Sebelum tindakan sebanyak 2 siswa $(5,71 \%)$ pada siklus pertama pertemuan 
pertama menjadi 17 siswa (48,51\%). pertemuan kedua sebanyak 19 siswa (54,29\%), dan pada siklus II pertemuan pertama sebanyak 24 siswa $(68,57 \%)$, pertemuan kedua sebanyak 23 siswa $(65,71 \%)$. (b) Data hasil tindakan kelas menunjukan bahwa siswa yang menanggapi pertanyaan Guru mengalami peningkatan. Sebelum tindakan sebanyak 3 siswa $(8,57 \%)$, pada Siklus I pertemuan pertama menjadi 18 siswa $(51,43 \%)$, pertemuan kedua sebanyak 15 siswa $(42,86 \%)$, dan pada Siklus II pertemuan pertama sebanyak 25 siswa $(71,43 \%)$, pertemuan kedua sebanyak 26 siswa (74,29\%). (c) Data hasil tindakan kelas menunjukan bahwa siswa yang mengerjakan soal di depan kelas mengalami peningkatan. Sebelum tindakan sebanyak 11 siswa $(31,43 \%)$, pada Siklus I pertemuan pertama menjadi 20 siswa $(57,14 \%)$, pertemuan kedua sebanyak 21 siswa (60\%), dan Siklus II pertemuan pertama sebanyak 31 siswa $(88,57 \%)$, pertemuan kedua sebanyak 29 siswa $(82,86)$.

Dalam uraian di atas dapat menjawab rumusan masalah yang telah ditentukan dalam penelitian ini. Berdasarkan hasil penelitian dapat disimpulkan bahwa pembelajaran dengan strategi Peer Tutoring sangat efektif dalam meningkatkan rasa penguasaan diri siswa dalam belajar matematika siswa kelas XII.MIPA.1 SMAN 2 Kota Jambi.

\section{DAFTAR PUSTAKA}

Afifah, Nur. (2011). Strategi Pembelajaran Tutor Sebaya untuk Meningkatkan Hasil Belajar Matematika Anak Berkesulitan Belajar Kelas IIIA SD Negeri Kepatihan Surakarta Tahun Pelajaran 2010/2011. Jurnal UNS.

Arjanggi, Ruseno, dan Titin Suprihatin. (2010). Metode Pembelajaran Tutor Teman Sebaya Meningkatkan Hasil Belajar Berdasar Regulasi-Diri. Makara, Sosial Humaniora vol. 14, no. 2, 91-97

Djamarah, Syaiful Bahri, dan Aswan Zain. (2006). Strategi Belajar Mengajar. 2006: Rineka Cipta.

Ekaristi, Murwani Dian. (2012). Efektifitas Bimbingan Kelompok dalam Meningkatkan Rasa Percaya Diri pada Siswa Kelas XI SMA Kristen 1 Salatiga. Salatiga: Universitas Kristen Satya Wacana.

Hanik, N. R \& Harsono, S. (2016). Peningkatan aktivitas dan Hasil Belajar Mahasiswa pada Mata Kuliah Anatomi Tumbuhan Melalui Model Pembelajaran Komparasi yang Berbasis Lesson Study. Jurnal Pendidikan Matematika dan IPA, Vol 7, N0 2, 25-31

Hasibuan, J J, dan Moedjiono. 2010. Proses Belajar Mengajar. Bandung: PT Rosda Karya.

Kosasih, E. (2014). Strategi Belajar dan Pembelajaran (Implementasi Kurikulum 2013). Bandung. Yrama Widya

Mujiarso, J. (2014). Peningkatan Aktivitas Siswa Melalui Pendekatan Matematika Realistik Pada Materi Kesebangunan di Kelas IX B SMP Negeri 1 Samalantan. Jurnal Pendidikan Matematika dan IPA, Vol 5, No 1, 1-10.

Rosanti, D. (2014). Penerapan Metode Pembelajaran Tutor Sebaya Untuk Meningkatkan Aktivitas Dan Hasil Belajar Siswa Di SMA Negeri 9 Pontianak. Jurnal Pendidikan Matematika dan IPA, 9(2), 1-10.

Satyani, Ida Ayu Putu, I Nyoman Dantes, dan I Made Candiasa. 2014. Pengaruh Model Kooperatif Teknik Tutor Sebaya Terhadap Prestasi Belajar Matematika dengan Pengendalian Kovariabel Kemampuan Penalaran Operasional Konkret. E-Jurnal Program Pascasarjana Universitas Pendidikan Ganesha vol. 4

Silberman, Mel. 2001. 101 Strategi Pembelajaran Aktif (Active Learning) terjemahan Sarjuli dan Azfar Ammar. Jakarta: Yakpendis.

Soemarmo, U \& Hendriana, H. (2014). Penilaian Pembelajaran Matematika. Bandung. Refika Aditama.

Tana, M. E. M., Supriyoko, S., \& Haryanto, S. (2017). Efektivitas model pembelajaran problem-learning dengan metode peer tutoring berbantuan geogebra pada dimensi tiga dalam upaya meningkatkan motivasi dan prestasi belajar matematika siswa. Wiyata Dharma: Jurnal Penelitian dan Evaluasi Pendidikan, 5(1), 37-43. 